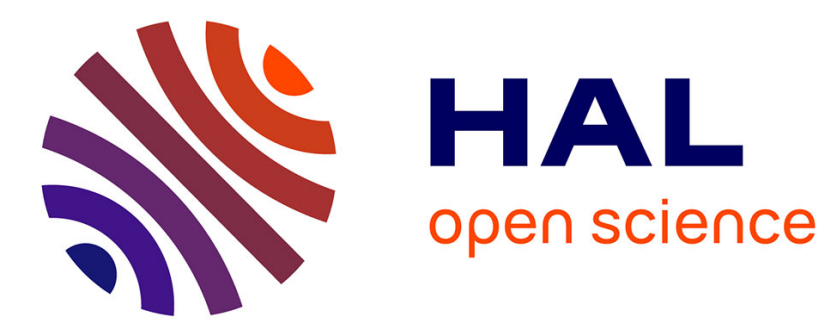

\title{
Dynamic Ontology Supporting Local Government
}

Mieczyslaw Owoc, Krzysztof Hauke, Katarzyna Marciniak

\section{To cite this version:}

Mieczyslaw Owoc, Krzysztof Hauke, Katarzyna Marciniak. Dynamic Ontology Supporting Local Government. 4th IFIP International Workshop on Artificial Intelligence for Knowledge Management (AI4KM), Jul 2016, New York, NY, United States. pp.36-49, 10.1007/978-3-319-92928-6_3 . hal01950008

\section{HAL Id: hal-01950008 \\ https://hal.inria.fr/hal-01950008}

Submitted on 10 Dec 2018

HAL is a multi-disciplinary open access archive for the deposit and dissemination of scientific research documents, whether they are published or not. The documents may come from teaching and research institutions in France or abroad, or from public or private research centers.
L'archive ouverte pluridisciplinaire HAL, est destinée au dépôt et à la diffusion de documents scientifiques de niveau recherche, publiés ou non, émanant des établissements d'enseignement et de recherche français ou étrangers, des laboratoires publics ou privés.

\section{(c)(1)}

Distributed under a Creative Commons Attribution| 4.0 International License 


\title{
Dynamic Ontology Supporting Local Government
}

\author{
Mieczysław Owoc, Krzysztof Hauke and Katarzyna Marciniak \\ Wroclaw University of Economics, Poland \\ \{mieczyslaw.owoc, krzysztof.hauke, \\ katarzyna.marciniak\} @ue.wroc.pl
}

\begin{abstract}
Nowadays in information society we face a huge amount of data and information sharing on the Web by customers of public administrator sectors. Services performed for customers from the nature are very flexible - so preparation ontology for such goals must include dynamic aspects. The goal of this paper is creation dynamic ontology for relationships type of $\mathrm{C} 2 \mathrm{C}$ (Citizen to City). It is especially important in knowledge management at the local level of administration in case of monitoring uncompleted matters, evaluation of effectiveness of clerks representing selected departments or in decisions of administration restructuring. In this paper we propose a dynamic-oriented knowledge model, designed to distribute and manage urban knowledge as a representative of local self-government. Ontology including mentioned knowledge management supporting is prepared using sophisticated Ontorion Fluent Editor.
\end{abstract}

\section{Introduction}

Description of the processes that citizens participate in modern society is very complex and cover all areas of human activities. On the other hand relationships between ordinary people (in fact customers) and public administration at different levels of ruling are essential for functioning of any society. Good ontology allows for better understanding of the mentioned processes and creates opportunity to manage efficiently social life in different areas.

There is relatively small number of research investigating nature of relationships between citizens and governments at the state as well as at the local levels (citizen-to-city: C2C). Despite of certain similarities (mostly participation of two essential components: people and government body) there are several significant features important for the relationships $\mathrm{C} 2 \mathrm{C}$ : common area of living and acting, communication, education and many others. Basically, research in this area is focused on an idea of smart city where more ambitious solutions are offered (see: Batty, 2013 and Townsend, 2014). As a result so- 
called urban knowledge can be introduced as general platform adequate for city society.

The main paper goal is presentation of ontology describing main components of the defined domain including dynamic aspects of its functioning. Therefore the following sections are present in this paper: discussion about the urban knowledge, demonstration of main areas covering $\mathrm{C} 2 \mathrm{C}$ model, presentation of initial version of ontology with active rules essential in the model and conclusion with synthesis of research findings.

\section{Specialty of urban knowledge as the informational in- frastructure essential in $\mathrm{C2C}$ model}

Climate and demographic changes, limited resources, growth of population, urbanisation, increasing importance of information and development of information technologies are forcing large and medium-sized cities to make changes in every area of their operational functioning. Beginning from integrating autonomously functioning ICT platforms through effective energy resources, raw materials and waste managing and ending with developing dialogue with citizens and making physical infrastructure changes.

The main aim of such upgrade is not only to achieve positive economic impact on a city, region, or a country, but mainly to prepare for meeting future needs of civilisation. Nowadays they are generated by the society which in fact is classified as an information society. Solutions used in cities all over the world (Amsterdam, Copenhagen, Montpellier, New York, Singapore, Wrocław, etc.) are no longer sufficient to provide proper communication between its users citizens, but has become an integral part of the present civilisation infrastructure. Such situation forces city governances into using effective management in all different branches of their urban economies. That will lead to the development of higher levels of efficiency, interactivity, flexibility, accountability essential to adapt to the rapid pace of changes which, indeed, is the ideological basis of well-known and used in the world concept of smart city.

Main factor of describing city as a kind of smart is intelligent management and knowledge management. It means that if the decision-making bodies make decisions regarding the development of the city they must take into consideration contractual six segments, aspects of the agglomeration: smart economy, people, governance, mobility, environment and living (Chourabi et. al., 2012). Figure 1 illustrates the pattern of relations occurring between so called sectors of the modern city. This classification describes how strong intersectoral cooperation should be provided to ensure effective decision making processes based on relevant knowledge. Such visualization shows also how crucial can be dependence on Information and Communication Technologies. The purpose of the existence and operation of ICT infrastructure is therefore necessary to integrate key information generated by its users on each field, which is to provide a 
complete list of requirements, guidelines for maintenance and improvements in aspects: ecological city life of its citizens, public safety, public services and the operation of any commercial and industrial activities.

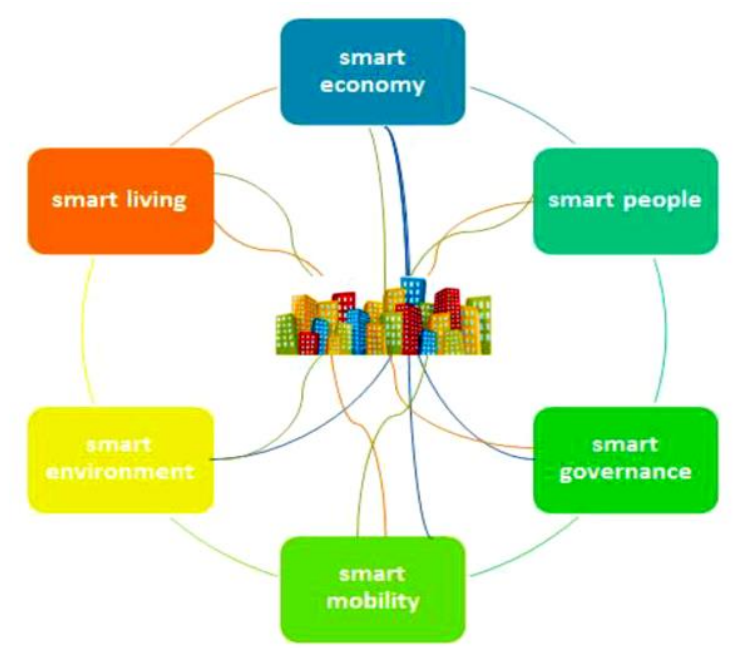

Figure 1. City as a system.

To ensure the effectiveness and efficiency of smart city it is crucial to apply all dedicated solutions related to appearing problems concerning each and every area of the city taking advantage of implemented ICT solutions. The existence of individual components, as autonomous entities is impossible. That is why it is important for decision-makers of a city to think of a process of making changes as a holistic investment and development. Decisions should be made not only on current information presented by mainly on gathered knowledge and experience.

Looking at the city from the perspective of the whole, complete, living organism allows decision-makers to pay special attention to the integration of urban infrastructures. That mechanism of making changes in one aspect relating results in other aspects make smart city as a "system of the systems".

Wherever processes of decision-making are found, through their algorithmicising, it is possible to use information support, using specially dedicated solutions. Strategic vision for the implementation of information systems in urban areas should be understood primarily through the integration of diverse information systems and customization them for the needs of residents, using all available communication channels and tools.

According to the author's knowledge, a key element for the pursuit of development in line with the reasons stemming from the macro-cities is an urban knowledge. Taking into account the results of enterprises market function- 
ing and the results that achieve through the use of knowledge management processes, the author believes that urban knowledge may be an aspect that will allow raising the competitiveness of cities, seeking to ensure the integration of infrastructure (mainly in the area of information technology, social and governance) and achieving spatial cohesion. Thus, the author believes that the improvement of management processes in the cities, on the basis of knowledge can contribute to the real fulfillment of assumptions Regional Development, the National Spatial Development Concept 2030 in 2030 at the local country.

Knowledge is not only one of the key resources of the enterprise, but also is the foundation, the starting point for determining the city's strategies, particularly for the implementation of management information systems. However, the organization cannot exist without human capital, so to be able to say that the company has knowledge, it is needed to take into account in addition to possession of selected information: skills, experience and qualifications of specialists in selected fields. The combination of these two elements is a complete understanding of each organization. Parallelly, paying attention to the continuity of the process of converting data into information and information into knowledge (see: Albescu et al., 2009).

Because of the persistence of highlighted perspectives knowledge is classified as an information resource and as an element of human capital. Each organization needs both to ensure proper functioning. It is reasonable to say that knowledge is nothing else than "a combination of everything: facts, phenomena and relationships between them, which is consciously perceived and recorded (in any way saved as real entities or conceptual) and can give to others, according to the intention of having knowledge in specific conditions and circumstances to arouse certain behaviours" (see: Bergeron, 2003).

Trying to define knowledge as an asset of such complex organization like city it is necessary to investigate more facts. Presented definitions of knowledge in organization are considered as basis but with certain are insufficient. To have holistic description of urban knowledge author consider adding some more features important for defining the intangible (see: Urban Knowledge, 2015).

Urban's knowledge, considered as an asset, needs to be of course possible to manage. Based on ongoing processes of city functioning, it was possible to notice, that knowledge of the city is created independently by entities functioning beyond the city's structure. This kind of knowledge must be secured in very specific way, is unique for long time. City's knowledge is created by local authorities, policy makers, social activists, institutions (educational medical, religion, ecological, others), $\mathrm{R} \& \mathrm{D}$, administration units, business. According to model of smart city (presented in the previous section), authors decide to divide city's knowledge into six aspects - see Table 1.

Table 1. Components of urban knowledge 

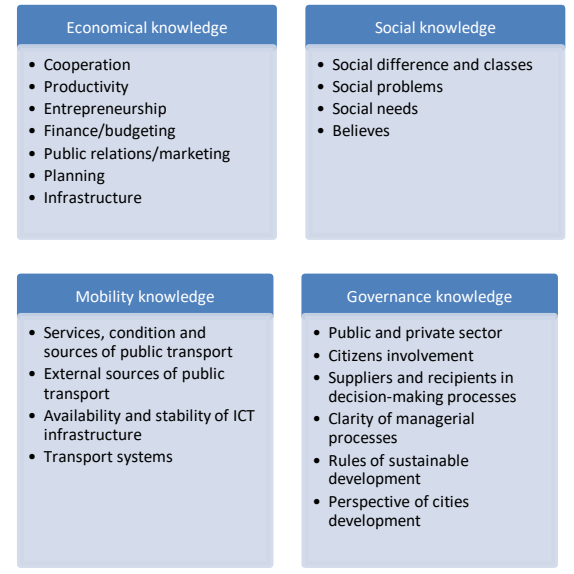
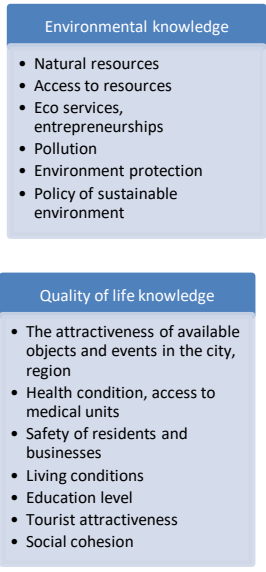

As we can see, urban knowledge can be understood as the summary of: economic knowledge, people knowledge, environment knowledge, mobility knowledge, governance knowledge and living knowledge embracing specified knowledge pieces.

Urban knowledge classified as the asset of the city can be managed. Urban knowledge management can be treated as a specially designed system that helps cities to acquire, analyse the use (re-use) of urban knowledge in order to make faster, smarter and better decisions, so that they can achieve a competitive advantage in case of covering cities stakeholders needs. Urban knowledge management covers management of information, knowledge and expertise available within the city, i.e. mobility, environment, social, managerial, economical by the creation, collection, storage, sharing and use, to ensure the cities future development based on well prepared decision plans. Urban knowledge management also emphasizes the two items related to knowledge management. Both accessible to, the information, experience, staff and their expertise and the technological, where the focus is on codifying knowledge, its acquisition, collection, analysis, storing and sharing at any time, by a specific user. The logical also is the fact that the development of knowledge takes place through the exchange of experiences, analysis, opinion, finding new sources of information, where the information systems are the basis to allow all of the actions.

In addition, each city must be aware that the overall urban knowledge management system cannot be based only on properly chosen technology" (Tiwana, 1999). Because of presented arguments, it is possible to propose Local Governments well-known e-commerce model: Consumer to Consumer (C2C) as adequate for supporting the urban knowledge management as the method of implementing their self-governance. Knowing that $\mathrm{C} 2 \mathrm{C}$ is model which describes process of exchanging goods, services between users on third-party business created to facilitate the transactions, authors may assume that $\mathrm{C} 2 \mathrm{C}$ in 
case of urban knowledge may be defined as model of exchanging the information and knowledge (urban) on-line between cities stakeholders by using knowledge sharing platform (Figure 2).

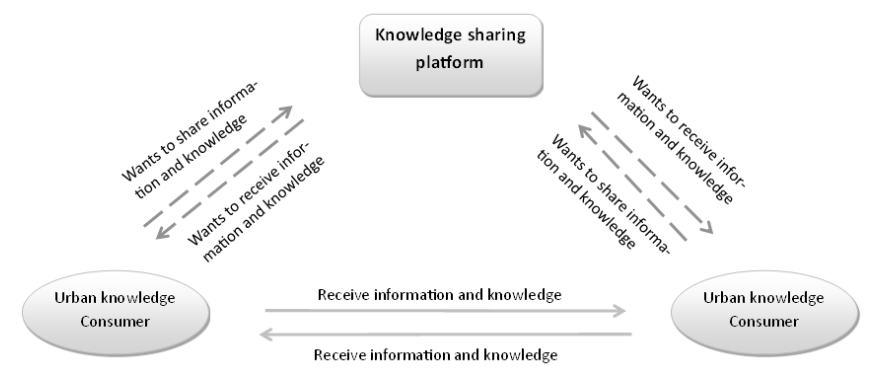

Figure 2. Urban knowledge in $\mathrm{C} 2 \mathrm{C}$ model for the city.

According to presented concept of urban knowledge, its categorization visualized in table 1 and model of C2C figure 2, urban knowledge management or urban knowledge transfer may be supported by information system in form of knowledge sharing platform. User of this platform are in general consumers of urban knowledge (e.g. citizens, local government units, administration officers, representatives of science, entrepreneurs, etc.). Knowledge sharing platform can be the perfect place to support knowledge gathering, storage and sharing for its users.

Urban knowledge sharing platform for can be a compendium of technological information, in accordance with the requirements of the concept of "knowledge grid for urban knowledge management", which means that:

1. Proposed Knowledge Platform will create a place where indicated institutions responsible for the creation of legal, laws and regulations, social workers, institutions interested or involved in the solving the cities problems (universities, research institutions, scientists, the media, journalists), independent entities interested in developing the city, individual specialists will be able to share content about actual city prospering in particular fields.

2. For platform users, platform becomes a compendium of knowledge about the urban knowledge (economy, people, environment, mobility, governance, living).

3. Platform will also provide a place of learning for specific social groups. The platform will include a module for e-learning, where the above group of interests will be able to create educational courses for specific groups of users.

4. Platform will be a place and a tool which will support the knowledge management process in the city. Defining the users of the platform, authorities are already informed about the group of interest in the city. Building the communication with the users ensure knowledge gathering. Using the plat- 
form as a tool for support city's management ensures also the integration of ICT infrastructure in the city and make the clarity and order in the city.

Considering development of dedicated knowledge portal at least the following aspects should be taken into account: purpose and audience, technology and tools useful for the creation and maintenance stages.

Platform can enable the integration of the information needs of citizens and all the entities interested. Information needs of citizens and all the entities interested. Table 2 presents potential lists of expectations of implementing C2C model in the city from perspective of chosen urban knowledge consumers: city's authorities, units cooperating inter-sectoral within the city and external stakeholders.

Table 2. Expectations of chosen urban knowledge consumers in $\mathrm{C} 2 \mathrm{C}$ model.
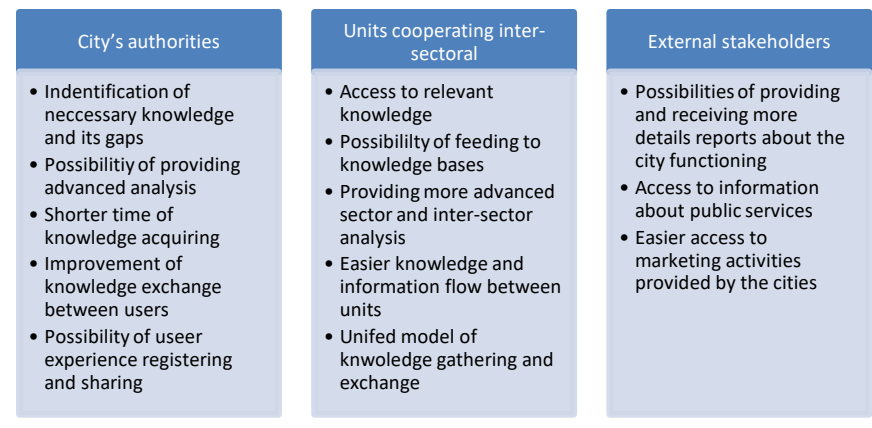

The idea of that platform is to provide the right kind of knowledge related to the particular recipients. In addition, the platform provides users the ability to communicate with each other: both the target group, which will be the citizens of the city, and the target group with the suppliers of knowledge and educational materials. Users will also have the ability to communicate using the tools (i.e., hut, video, mobile, blogs) with the other participants will help to alleviate the barriers between different social groups, and at the same time will help to increase the effectiveness. Platform for manage the urban knowledge (presented in Figure 2) and in the same time ensure existence of $\mathrm{C} 2 \mathrm{C}$ model, can be a compendium of technological information, in accordance with the requirements of the concept of "knowledge grid for urban knowledge management" (Hauke et al., 2015), which means: centralization of any knowledge resources focused on C2C model, inclusion of crucial components (economy, people, environment, mobility, governance, living) and easiness of urban knowledge management. 
Considering development of dedicated knowledge portal at least the following aspects should be taken into account: purpose and audience, technology and tools useful for the creation and maintenance stages.

\section{Areas of activities of a Local Self-Government}

Local Self-Government (LSG) can be identified with local government as a specific form of public administration oriented on some commune. There are several features of this sort of administration; widely accepted are: autonomy, sovereignty, home ruling in every case acting in a small scale and focusing on local matters.

According to the aims of a Local Self-Government all domains connected to local community should be included to its activities. Therefore the regulations in the following areas must be present:

- society life (eg. people registering, people mobility, education at the lower levels, paying taxis and others identified with personal needs of habitants),

- infrastructure maintaining (in terms of services of crucial means: water delivering, sewers services, electricity and gas supplying, local communication and the like),

- business services (business evidence, office renting, taxation, commercialization etc.).

Analysing different city portals we discover variety solutions addressed to local society and other potential customers (business and travellers for example). Our research is focused on representatives of three categories of cities: megacity (with more than 10 million habitants), middle city (range 1-10 million habitants) and relatively small city (less than 1 million habitants). Additionally we selected cities from different parts of Europe, thus three cities were chosen: London, Berlin and Wroclaw. As a result considering local administration we discovered the following divisions representing administration offices of different cities in presented in Table 2 .

Presentation of Local self-Government organizational aspects we may conclude that all urban knowledge and activity areas are present in particular cities. Some of divisions are specific for megacity (London Immigrants and Refugees Departments), some are strictly oriented on city affairs (Berlin as Economic Centre) while specific nature of infrastructure for smaller city (Wroclaw Municipal Greenery). In all cases $\mathrm{C} 2 \mathrm{C}$ model expresses complex nature of entitygovernment relationships including its dynamical aspect. 
Table 2

Examples of divisions in selected European Cities

\begin{tabular}{|c|c|c|c|c|}
\hline $\begin{array}{l}\text { Urban } \\
\text { knowledge }\end{array}$ & $\begin{array}{l}\text { Activity } \\
\text { Areas }\end{array}$ & London & Berlin & Wroclaw \\
\hline $\begin{array}{l}\text { Social, } \\
\text { Quality of } \\
\text { life }\end{array}$ & $\begin{array}{l}\text { Service of } \\
\text { habitants }\end{array}$ & $\begin{array}{l}\text { Communities, } \\
\text { Migrants and } \\
\text { Refugees, } \\
\text { Older people }\end{array}$ & $\begin{array}{l}\text { Labor Mar- } \\
\text { ket, Personal } \\
\text { Data Evi- } \\
\text { dence }\end{array}$ & $\begin{array}{l}\text { Registering } \\
\text { and archives } \\
\text { of Personal } \\
\text { Data }\end{array}$ \\
\hline Social & Education & $\begin{array}{l}\text { Education and } \\
\text { youth }\end{array}$ & $\begin{array}{l}\text { Living Study- } \\
\text { ing and } \\
\text { Working }\end{array}$ & $\begin{array}{l}\text { Enrollment, } \\
\text { scholarships }\end{array}$ \\
\hline $\begin{array}{l}\text { Social, } \\
\text { Quality of } \\
\text { life }\end{array}$ & $\begin{array}{l}\text { Health, } \\
\text { Culture }\end{array}$ & $\begin{array}{l}\text { Healthy ine- } \\
\text { qualities, } \\
\text { Healthy envi- } \\
\text { ronment, } \\
\text { Sport, Regen- } \\
\text { eration, Arts } \\
\text { and Culture }\end{array}$ & $\begin{array}{l}\text { Services and } \\
\text { Contacts }\end{array}$ & $\begin{array}{l}\text { Health infor- } \\
\text { mation, Ser- } \\
\text { vices, Cultural } \\
\text { Institutions } \\
\text { Mgmt }\end{array}$ \\
\hline $\begin{array}{l}\text { Mobility, } \\
\text { Social }\end{array}$ & $\begin{array}{l}\text { Communi- } \\
\text { cation }\end{array}$ & Transport & $\begin{array}{l}\text { Public } \\
\text { transport }\end{array}$ & $\begin{array}{l}\text { Car and Driv- } \\
\text { ing Licence, } \\
\text { Public transport }\end{array}$ \\
\hline $\begin{array}{l}\text { Govern- } \\
\text { ment, } \\
\text { Environ- } \\
\text { ment }\end{array}$ & $\begin{array}{l}\text { Infrastruc- } \\
\text { ture }\end{array}$ & $\begin{array}{l}\text { Housing and } \\
\text { land, Renting }\end{array}$ & $\begin{array}{l}\text { Commercial } \\
\text { Trade and } \\
\text { Real Estate }\end{array}$ & $\begin{array}{l}\text { Real Estate } \\
\text { Mgmt, Munic- } \\
\text { ipal Greenery }\end{array}$ \\
\hline $\begin{array}{l}\text { Social, } \\
\text { Quality of } \\
\text { Life }\end{array}$ & Safety & $\begin{array}{l}\text { Policing and } \\
\text { Crime }\end{array}$ & $\begin{array}{l}\text { Services and } \\
\text { Contacts }\end{array}$ & $\begin{array}{l}\text { Municipal } \\
\text { police }\end{array}$ \\
\hline $\begin{array}{l}\text { Economi- } \\
\text { cal }\end{array}$ & $\begin{array}{l}\text { Investment, } \\
\text { Business } \\
\text { Services }\end{array}$ & $\begin{array}{l}\text { Business and } \\
\text { Economy, } \\
\text { Research and } \\
\text { Analysis }\end{array}$ & $\begin{array}{l}\text { Berlin as } \\
\text { Economic } \\
\text { Centre, In- } \\
\text { vesting in } \\
\text { Berlin }\end{array}$ & $\begin{array}{l}\text { Urban In- } \\
\text { vestment, } \\
\text { Public pro- } \\
\text { curement }\end{array}$ \\
\hline
\end{tabular}

\section{Ontology for Local Self-Government Knowledge Management}

Before the municipality as a basic unit of local self-government are facing new challenges. It plays an integral role in relation to the inhabitants and entities operating in the area. The implementation of the mission of the municipality is carried out on the basis of conditions resulting from state policy in relation to the given areas, local conditions, which are the result of activities of municipalities themselves. In this process, you should not forget about the stakeholders 
who live in the municipality or do business. These are the entities that will represent the new quality we are dealing with, which is called attractiveness. In order for the municipality to be regarded as attractive, residents and businesses must actively participate in it. Their effectiveness is supported, among other things, by information technology.

Local government at the commune level has experienced a period of very dynamic changes over the last few years. These changes are influenced by many factors. Among them, information technology plays an important role. The opportunities that web services now offer should be adapted to the management of the municipality. The changes that result from the use of information technology are adapted by business organizations. There may be some delays in the implementation of modern solutions that support management processes. This includes the nature of the impact and the way local government units are managed as a whole. The inflexible mechanisms of information flow and the monopoly of decision-making for the stakeholders of the municipality (inhabitants, companies, public benefit organizations) have led to the status of municipalities (see Figure 2). Stakeholders do not always accept decisions made by municipalities. This critical opinion arises mainly from the ignorance of activities in a given area and the lack of contact with those who take on behalf of the municipality.

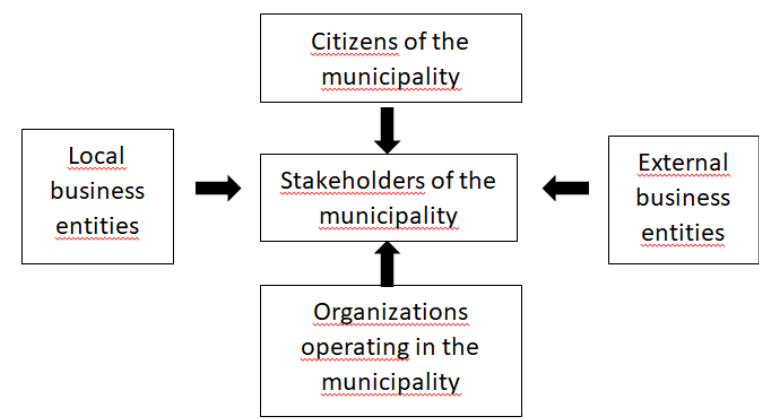

Figure 2. Stakeholders of the municipality

The mission of the public administration is resident supporting in the defined area. Regardless of geographic location, public administration has to solve the problems of its inhabitants. Public administration is a complex organ, which can distinguish the following categories:

- inhabitants,

- $\quad$ cases referred to the office under defined conditions,

- competent authority of the public administration, which solves particular problems of the defined matters.

Public administration departments in order to complete inhabitant's matters use: domain knowledge and in particular cases defined earlier procedures. 
Knowledge and procedures that result from established law and current regulations in force in the territory.

From the organizational point of view public administration it is divided into divisions entitled to complete entities (inhabitants, Business, other institutions) matters e.g.: impact areas of public administration, offices, and departments.

The Figure 3 shows infrastructure of Local Self-Government activities.

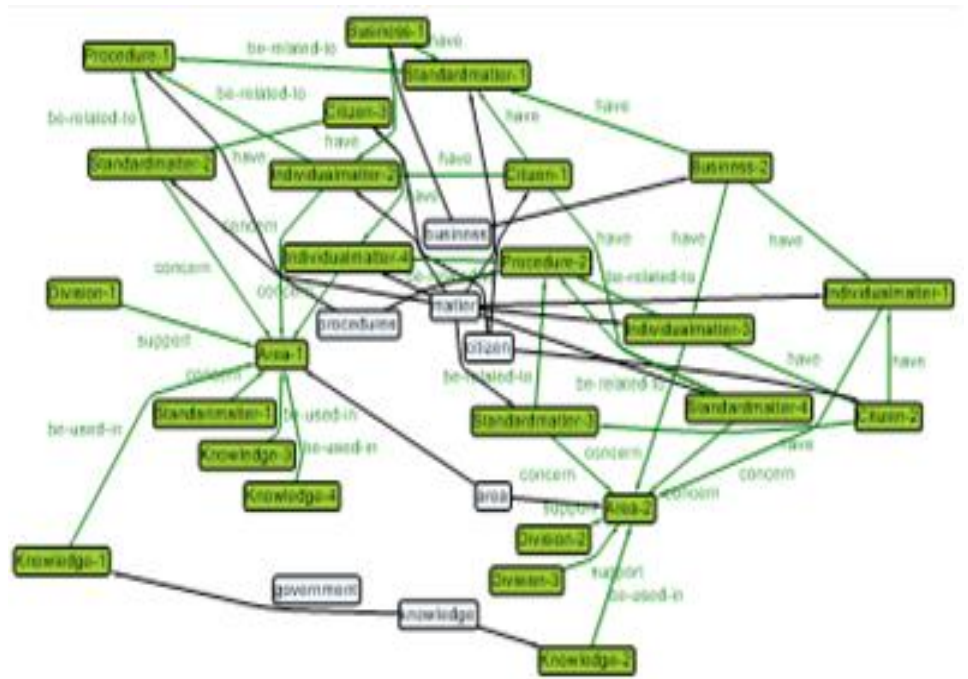

Figure 3. Main categories of Local Self-Government activities

The particular categories are the components of the city public administration infrastructure. Relationships among particular components can be formulated as direct on indirect. Faced with the direct relationships between its elements are operators, as steps. Below we will discuss examples of ontologies occurring between the elements of the environment of public administration.

Example 1:

Operator: concern; elements: matters (standard and individual matters), areas 


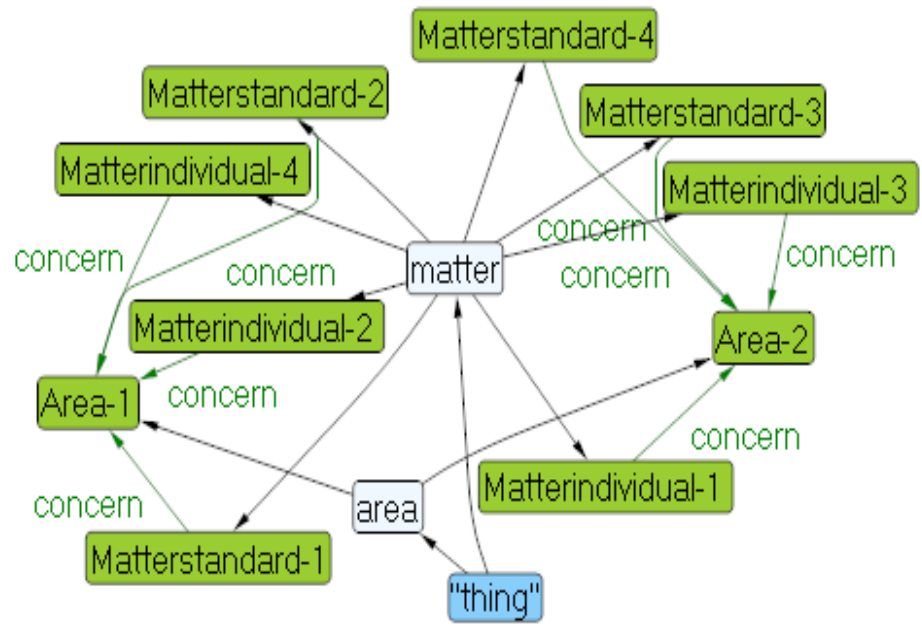

Figure 4. Ontology - matter "concern" area

\section{Example 2:}

Operator: has; elements: matters (standard and individual)), citizens, business

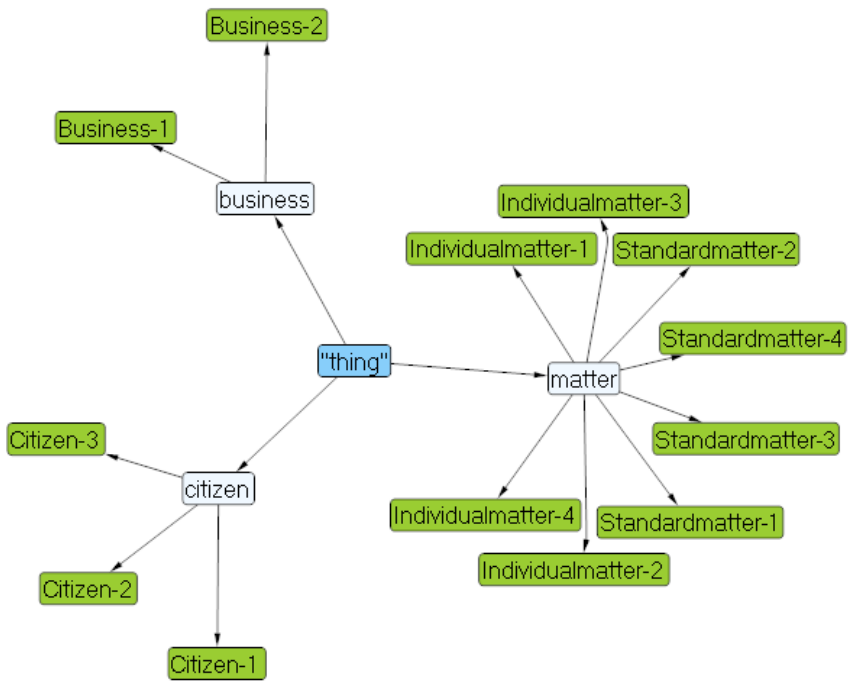

Figure 5. Ontology - matter "concern" area

Example of question to ontology: 
Q1. Who-Or-What uses Area-2 ?

Ans. Knowledge-2

Q2. Who-Or-What has StandardMatter-4?

Ans. Citizen-1

Q3. Who-Or-What is-related-to Procedure-1 ?

Ans. StandardMatter-1

StandardMatter-2

IndividualMatter-1

IndividualMatter-2

Q4. Who-Or-What is-related-to Procedure-1 and concerns Area-2 ?

Ans. Matterindividual-1

The presented ontology allows to organize the components of the municipality. The consequence of this may be the implementation of an active rule. Thanks to this traditional management in the municipality can be implemented automatically. Many tasks in the municipality are repetitive. If we can see this repetition as an algorithm, then it means that we can apply the rules without any problems. Active rules are determined by four operations:

- add,

- modification,

- moving,

- deleted.

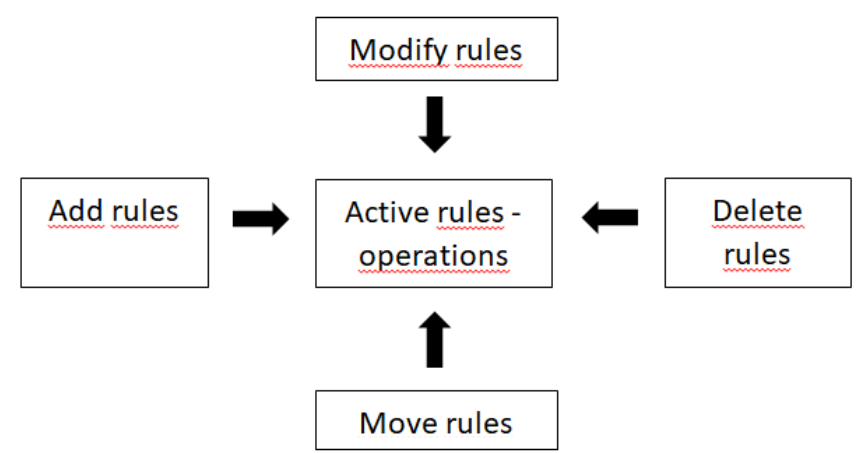

Figure 6. Active rules - operations.

However, for two operations be very careful. This is an operation to move and delete an object. In this case, there can be no such approach, which does not take into account the mechanism of recording the history of the opiate. 


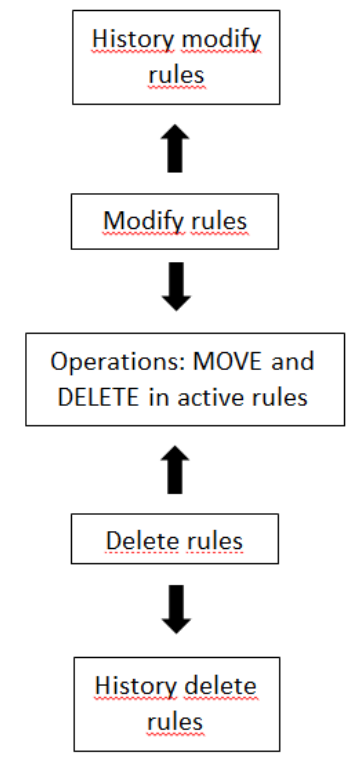

Figure 7. Operations MOVE and DELETE in active rules.

Active rules:

1. Example KnowledgeInsert

- If citizen is new then add to citizen.

- If business is new then add to business.

- If new law is created then add to use.

- If new local politics then add to use.

- If business is new then add to taxes.

- If knowledge is new then knowledge add to Area-1 or Area-2.

- If matter is incomplete then matter is back to citizen.

- If matter is Division-1 then use Procedure-1 or Pro-cedure-2.

2. Example KnowledgeDelete

- If matter has status=TRUE then matter move to archives.

- If knowledge is outdated then knowledge delete from actual knowledge.

- If citizen it has taken care of all matter then citizen delete from ontolo-

gy.

- If procedure unresolved then procedure delete from ontology.

- If business is liquidated then delete from taxes.

- If the laws are outdated then laws move to archives.

- If business gone bankrupt then move to archives.

- If business gone bankrupt then business from ontology 
To develop ontologies have been selected basic objects handled by the public administration. For example, a big number of objects selected to develop ontologies denotes the complexity in which the public administration has to carry out its tasks. It should be stressed - as a result of the mission of public administration - that all tasks performed by the public administration must be coherent with all regulations formulated for the society (see: Breuker et al.). In the case of addressing particular matters for the LSG there are different procedures prepared for variety customers (citizens or representing business).

Because of their mission, they do not compete with each other so much. However, mechanisms are created that should motivate the activities of the municipality for the needs of the environment. The community's stakeholder setting will make the community attractive. In this case you can talk about the development spiral of the municipality. Increasing the attractiveness of the municipality results in a greater interest in the activities of the municipality by residents and businesses, which is on its territory. Through the economic mechanisms, that is, taxes on business activities by the business entity and opinion of the inhabitants of the municipality and also their taxes increase the per capita position of the municipality. This in turn translates into the interest of the municipality concerned by stakeholders who want to live in its territory or do business. At present, such activities make it easier for municipalities to raise funds from central funds or from the European Union.

\section{Conclusions}

Analysing services essential in $\mathrm{C} 2 \mathrm{G}$ models we discover specific aspects and context when customers become citizens and government is limited to local area. The main findings of the research are:

- $\quad \mathrm{C} 2 \mathrm{C}$ model can be defined as sub-model of $\mathrm{C} 2 \mathrm{G}$ model;

- Components of presented ontology are partially similar despite of different areas of activities (comparison $\mathrm{C} 2 \mathrm{C}$ abd $\mathrm{C} 2 \mathrm{G})$;

- Dynamic aspects of ontology must be represented in more advanced ways as active rules;

- Actually the tool used in the research offered very limited way of expression dynamic knowledge.

In the nearest future we'll try to analyse and evaluate other tools for the defined $\mathrm{C} 2 \mathrm{C}$ model. 


\section{References}

[1] Albescu F., Pugna I., Paraschiv D.: Cross-cultural Knowledge Management, Informatica Economica vol.13, no 4/2009

[2] Batty M.: The New Science of Cities. MIT Press, 2013

[3] Bergeron B.: Essentials of Knowledge Management, John Wiley \& Sons, New Jersey 2003

[4] Breuker J., Casanovas P., Klien M.C.A., Francesconi E.: Law, Ontologies and Semantic WEB. IOS Press, 2009

[5] Hauke K. Kutzner I., Marciniak K., Owoc M.: Creation of the Urban Knowledge Portal: E-learning and Knowledge Inventor Context., The $11^{\text {th }}$ International Conference on Semantic, Grid and Knowledge - SKG'2015 Beijing, Chiny

[6] Tiwana A.: Knowledge Management Toolkit, PTR 1999

[7] Townsend A.M.: Smart Cities: Big Data, Civic Hackers, and the Quest for a New Utopia. W. W. Norton \& Company, 2014

[8] Berlin Haupstadt - http://www.berlin.del

[9] Urban Knowledge - http://www.igi-global.com/chapter/knowledgecreation-urban-knowledge-environment/25482 (available at May 2015)

[10] London City - http://www.london.gov.uk/

[11] Wroclaw miasto - http://www.wroclaw.pl/ 